\title{
The Sacred Guest and the Ungrievable Sacrifice: communitas at the Theatre
}

DOI 10.1515/jcde-2017-0010

\begin{abstract}
Based on Vazha-Pshavela's narrative poem of the same name, Roland Reed's and Synetic Theatre's play Host and Guest premiered in Arlington/VA in 2002 and was remounted to high critical acclaim in 2008. In the wake of the terror attacks of 2001, it explores themes of hospitality, ritualistic scapegoating, and of grieving that which Judith Butler has called an "ungrievable life." Reed's play invites a discussion of how contemporary theatre in what is generally called 'the global North' investigates the culture of hospitality in the light of simultaneous border consolidation and a decline in national sovereignty in a globalised world. Drawing on Roberto Esposito's discussion of the foundation of community as a relationship of mutual obligation and on Butler's suggestion to redefine kinship as a relation of choice, the focus of this paper is on theatre's sounding of the extent and the limits of hospitality in the face of migration that is often regarded as a threat, and on the theatre's potential for creating hope.
\end{abstract}

Keywords: community, grievability, Giorgio Agamben, homo sacer, hospitality, Host and Guest, Judith Butler, kinship, pharmakós, Roberto Esposito, sacrifice, scapegoat, Synetic Theatre, utopia, Wendy Brown

Two communities steeped in mutual hatred, an accidental meeting on a mountain top, an evening of celebration, a human sacrifice, a forbidden burial, then a fast descent into even more violence, culminating in a suicide: the plot of the concise dance theatre piece Host and Guest (2002) is told fast. But between the posts of this bare structure, the play expands to explore with powerful impact and kinetic energy the broader questions of hospitality and community, ritualistic scapegoating, and grievability, as it ardently criticizes the contemporary urge to exclude rather than to include. Commissioned, produced and first performed by Washington-based theatre and performance company Synetic Theatre in 2002, the play text was adapted by Roland Reed from a famous Georgian narrative poem by Vazha-Pshavela. The poem, "Host and Guest" (1893), is set against the backdrop

*Corresponding author: Julia Boll, University of Konstanz, Germany, E-Mail: j.boll@uni-konstanz.de 
of the Kisti-Khevsuri conflict in the Caucasus region in the $18^{\text {th }}$ and $19^{\text {th }}$ century. The relatively short play - the typescript runs to a total of eight pages, although the performance is about 75 minutes long - was directed by company founder Paata Tsikurishvili, who came to the United States from Georgia in the late 1990s. After performances in 2002 and 2004, chiefly in the Washington, DC area, the play was brought back to the stage in 2008 (again staged at the company's home in Arlington, VA).

The play opens on a chance encounter between two strangers: Zviadauri, from the ethnic group of Christian Khevsuris, and Joqola, of the Muslim Kistis, meet at night while both are hunting in the same forest in the mountain region in the Northern Caucasus, in the Georgian Pankisi Gorge in Kakheti close to Chechnya, where the Kist people live. Joqola invites Zviadauri to his home, not recognising him as an old enemy who has already killed many members of the Kisti community. Over the course of the evening, a friendship develops between them, despite their communities' mutual hatred:

Joqola ...I believe our custom, like yours, makes a guest sacred. We have a saying, "The guest will be the last to die."

Zviadauri We share that sacred trust.

Joqola "Whoever thirsts for hostility,

Let his heart dam up his blood,

Let his feet stand in blood,

Zviadauri Let his wine be turned to blood

Both Let it saturate his bread.” (Reed, Host and Guest C, 2)

They celebrate their young friendship with food, music and dance, but when the other Kisti villagers learn that Joqola gives shelter to the enemy in his house, a conflict between two ancient laws unfolds. The community demands he turn over his guest, so that Zviadauri can be killed in revenge and sacrificed on the grave of Dara, one of the Kisti he killed. Joqola refuses to surrender Zviadauri and refers to the ancient law of hospitality, which states that a guest is sacred, that "[ $[$ ] he guest will be the last to die" (2), but his insistence is met with hostility:

Mullah We have laws -

First Kisti Ancient laws!

Mullah We will throw you and your guest off a cliff if we like.

Second Kisti How could you take this murderer of our people into your home? ...

Joqola ... He is my guest! My guest! His hands could be flowing with my family's blood, and yet I cannot betray him. ... Musa, let him go, we don't attack an unarmed man. I ask this as your longtime friend. When he leaves my home, do what you please with him....

Musa You fool. You fool, if you go against your neighbors, your town, we'll tie you up like a pig and take you away, too! How dare you go against our common decision? What we decide becomes our law, and you act against us for the sake of this infidel. You treat your brothers 
like enemies. After today you have no brothers, no friends. Joqola, you are a pariah dog from this time onward. (Reed, Host and Guest F, 4)

In the two scenes above, both Joqola and the members of the Kisti community cite long-established rules which they regard as integral to the community's notion of self. The violations of these rules are considered so grave that they will immediately lead to the violator being ousted from the community, and further, to the violator's status as a person being revoked. This clash of two opposing understandings of what defines the community corresponds with Roberto Esposito's writing on the foundations of communities. He explores the roots of the concept etymologically, by refuting the general reading of the term: that "community" refers to a common good and to common values which define the individual members of the community (and their belonging to the same), as is alluded to in the above scene by Musa's insistence on a 'common decision' that 'becomes our law' which the individual member of the community cannot defy. Rather, Esposito derives, via Jean-Luc Nancy, ${ }^{1}$ from the term which originates the noun communitas a new reading of what a community could also be, how it could and perhaps should also be understood: as a relationship of obligatory mutuality. In the communal relationship, Esposito identifies a common lack that always (and continuously) has to be filled by a gift, the munus, which the individual subject gives to the community, yet which is not defined as a good to be claimed:

The munus (gift) that the communitas shares isn't property or a possession. It isn't having, but on the contrary, is a debt, a pledge, a gift that is to be given, and that therefore will establish a lack. The subjects of a community are united by an "obligation" in the sense of that we say “I owe you something”, but not "you owe me something”. (Esposito 6)

The two laws in conflict in Host and Guest both appear to be communal laws. The first denotes who is part of the community and will be protected by it in contrast to the one whose life can and will be taken as sacrifice, and the second, the one stating that one owes hospitality to the guest, is the law that echoes Esposito's suggestion of how the concept of communitas can also be understood: as a gift to be given to the other. Significantly, Joqola considers the notion that he owes his hospitality to Zviadauri as more essential than the idea that the community has a claim on the life of his guest. As can be derived from the scene above, in which

1 Esposito refers to Nancy's 1986 publication La Communauté désœuvrée (Paris: Christian Bourgois; trans. Peter Connor et al. The Inoperative Community, Minneapolis: University of Minnesota Press, 1991). 
both men join in a recital of the traditional saying on hospitality, Zviadauri understands the obligation in the same way.

Nevertheless, Joqola is cast out of the community, the Khevsuri enemy Zviadauri is taken away and killed in the cemetery, and thus the sacred custom of the sanctity of the guest is broken, though the sacrifice is spoilt: Zviadauri refuses to submit:

1st Parishioner Don't let him spoil the sacrifice!

Mullah I, Zviadauri, will be sacrificed as Dara's slave.

Zviadauri Give Dara a dog. (Reed, Host and Guest G, 5)

The sacrifice is of course not only spoilt because Zviadauri refuses to submit, but also because the guest is sacred, and sacrificing that which is denoted as sacred means that a principal taboo is being broken. At this point, the theatrical representation of the concept that Giorgio Agamben calls the homo sacer, or the bare life, gains relevance, tied up as it is with conceptions of political and religious exclusion and the idea of the sacrifice. Agamben identifies the bare life as the one who, having lost their civil rights and their social and legal status, "may be killed and yet not sacrificed" (Agamben 8; emphasis in the original).

Agamben's project has been discussed widely, and the critique centres most often on his discussion of sovereignty and the nation state, but also on his perceived 'negative' reading of the bare life and the concept of biopolitics. Esposito in particular is quite sceptical towards Agamben's de-historicized approach to biopolitics (Campbell 50) and proposes, himself, a more "affirmative biopolitics” (51-2). Jacques Rancière aligns Agamben's central thesis strongly with Hannah Arendt's equation of the subject of human rights with a deprived form of life (Rancière 306) and, like Esposito, disagrees with the implied rejection of rights discourses in Agamben, whom he charges with "radicalising” Arendt's thesis (301). ${ }^{2}$ Jacques Derrida criticises Agamben's partial conflation of the sovereign (whom Agamben reads as the embodiment of bios, as political life) and the homo sacer (whom Agamben casts as the embodiment of zoë, the bare life), reasoning that this conflation points at a de-historicized understanding of biopolitics on Agamben's part, which he feels robs the argument of its base (Derrida 421-35). Perhaps most relevant for the play at the centre of this article, Wendy Brown maintains that Agamben's argument begs “the question of where political sovereignty resides, what or who has it, and whether and why it makes sense to call hyperbolic and extra-legal expressions of state power 'sovereign"” (Brown

2 Rancière refers here to Arendt's 1951 publication The Origins of Totalitarianism (New York: Harcourt Brace). 
86), arguing that features of sovereignty are not even that closely linked to the nation state anymore, but have instead migrated towards global capital and to religiously-sanctioned violence (71). Brown's observation can be read in parallel to Host and Guest's seemingly "tribal" and pre-political community and its violent expulsion of both the Othered enemy and the member of the community who violated the community's "sovereign" decision, to the point that the play becomes an analogy of religiously and socially sanctioned violence and of the contemporary renewed "hysterical obsession" with everything foreign (125).

From Agamben's model, and indeed also from the critique it invites and subsequent discussions on the bare life, it can be concluded that the figure is tied up closely with conceptions of community and of religious, social and political exclusion. But in order to understand the function of this figure and to define the excluded, the community and its sense of self must also be considered. Precisely because it is historically so connected both to religious ritual and the political (which were not, originally, separate), the contemporary discussion of the figure relates to the demarcation of communities (and by extension, of democratic societies) as well as to lingering conceptions of sacred and desecrated, of taboo. In this sense, the figure may be regarded as a reincarnation of the scapegoat figure and the ancient ritual and sacrifice on the Western stage, or rather: the bare life as it has been discussed in current political and cultural thought finds its predecessor and analogy on the ancient as well as on the contemporary theatrical stage.

In connection to ritual and tragedy, the role of the scapegoat has been discussed extensively, though perhaps not always thoroughly, by René Girard. In both The Scapegoat (1986) and in Violence and the Sacred (1988), he writes about the ancient pharmakós-rite ( $\varphi \alpha \rho \mu \alpha \kappa o ́ \varsigma)$, the custom whereby a member of the community is ritualistically sacrificed or exiled from the polis as a scapegoat. ${ }^{3}$ Girard lists the social categories from which the victims of scapegoat rites are drawn in ritual, naming "vagabonds, beggars, cripples" (268). He is also one of the few scholars to explicitly look at the figure of the scapegoat in dramatic literature and on stage, though his work on the scapegoat has been charged with the conflation of the term 'scapegoat' and the concept of pharmakós. ${ }^{4}$ The loose and often interchangeable use of both terms by Girard as well as in contemporary

3 The term pharmakós here applies both to the rite and to the victim of the rite (cf. Girard 9-10). 4 For example, by Peter Winch (in "Inattentive readings," Times Literary Supplement, March 20, 1987: 290), and by Mary Douglas (in "The Go-Away Goat," in: The Book of Leviticus. Composition \& Reception. Eds. Rolf Rendtorff and Robert A. Kugler. Leiden: Brill, 2003. 121-41.), but also by David Dawson (in Flesh Becomes Word: A Lexicography of the Scapegoat, or, the History of an Idea. East Lansing: Michigan State University Press, 2013). 
thought, in connection to its central role in the foundation and sustainment of communities, invites a closer look at the terminology.

Derrida notably deconstructs the concept of the pharmakós in the second part of his essay “Plato's Pharmacy” (1968), which draws on Plato's Socratic dialogue Phaedrus (ca. 370 BC). Amongst other subjects, Plato's text discusses the origins of the written word by describing it as both a poison and a cure (pharmakon) (Derrida 70). Pointing out the lexical chain of connection between words used by Plato - pharmakeia-pharmakon-pharmakeus - Derrida marks that the term pharmakós, though heavily implied by the chain, "seems strikingly absent from the 'Platonic text"' (129). "The character of the pharmakós has been compared to a scapegoat," Derrida writes. "The evil and the outside, the expulsion of the evil, its exclusion out of the body (and out) of the city - these are the two major senses of the character and of the ritual" (130). He points out that the ceremony of the pharmakós

played out on the boundary line between inside and outside, which it has as its function ceaselessly to trace and retrace ... The origin of difference and division, the pharmakós represents evil both introjected and projected. Beneficial insofar as he cures - and for that, venerated and cared for - harmful insofar as he incarnates the powers of evil - and for that, feared and treated with caution. Alarming and calming. Sacred and accursed. (133).

Since the pharmakós, that which is expelled from civic life, 'the outside', is never discussed by Plato, who concentrates on 'the inside', there is a thought-provoking conceptual link between the bare life as outlined by Agamben (equally marked by its taboo status and ensuing invisibility to the public eye) and Derrida's assertion that the pharmakós is by implication nevertheless present in Plato's Phaedrus, central to the discussion and defined by its very absence because it leaves a tangible trace within the text and with regard to the wider implications of the text.

In Host and Guest, the pharmakós-ritual occurs at the centre of the play, marking the decisive moment after which there is no escape from the spiral of violence. At the moment of Zviadauri's death, his limit status becomes apparent: he turns into a poison for the community, which by sacrificing the sacred guest on the graves of the community's dead projects evil onto the enemy and at the same time introjects it by descending into abject violence. Yet he also stands for a potential cure by signifying the possibility of what a community could also be - a hopeful, utopian society, as it were, where the communal relationship is created by the members of the community performing the mutual offering of hospitality and friendship.

After the villagers have left the site, another taboo is flouted: Aghaza, the host's wife, grieves for the enemy and starts to bury him, leading to her being haunted by the dead: 
[Aghaza] cautiously moves to the corpse, falls on her knees and lets her weeping flood over him, giving herself over to her grief without restraint. ... Suddenly, an angry sound comes from the graves; the departed souls cry out against her as clouds swirl around her. We can just make out the cries of the dead:

Dead Souls (variously) What have you done!

Have you no conscience?

May God Almighty turn his anger against your head and against your family!

Shame!

Traitorous woman!

She runs off in panic. She looks behind; the dead pursue her.

(Reed, Host and Guest I, 6)

In an attempt to contextualize the extraordinariness and outrageousness of Aghaza's act of mourning and attempted burial of the dead Zviadauri, theatre critic Tim Treanor describes it as "an act as remarkable as an American praying for the soul of [11 September 2001 suicide attacker] Mohammed Atta" (Treanor n. pag.). In the act of burial and its disregard of the community's ethical order and cultural norms there is an echo of Sophocles' Antigone to be found. Although the conflict in Host and Guest at first appears to be one between two communal laws, albeit outside a visible state structure, they also seem 'pre-political', related to the principle of kinship. In her discussion of the eponymous figure, Judith Butler at first outlines Hegel's reading of Antigone as a conflict between kinship on the one hand and ethical order and state authority on the other, ${ }^{5}$ but she then departs from his understanding of kinship as being situated "at the limit of...'the ethical order,' the sphere of political participation but also of viable cultural norms" (Butler, Antigone's Claim 3), stating that already in Sophocles's play, kinship and sovereignty are "metaphorically implicated in one another in ways that suggest that there is, in fact, no simple opposition between the two" (6). Butler points out that Antigone, the figure, does not represent kinship

in its ideal form but its deformation and displacement, one that puts the reigning regimes of representation into crisis and raises the question of what the conditions of intelligibility could have been that would have made her life possible, indeed, what sustaining web of relations makes our lives possible, those of us who confound kinship in the rearticulation of its terms? What new schemes of intelligibility make our loves legitimate and recognizable, our losses true losses? This question reopens the relation between kinship and reigning epistemes of cultural intelligibility, and both of these to the possibility of social transformation. (Butler, Antigone's Claim 24)

5 Throughout her analysis, Butler refers to G.W.F. Hegel's 1807 publication The Phenomenology of Spirit, citing both A. V. Miller's 1977 translation into English (London: OUP) and the German Suhrkamp-edition (Phänomenologie des Geistes. Werke 3. Frankfurt: Suhrkamp, 1970). 
Noting that Antigone defines kinship through her actions, Butler asks if it should perhaps be described as "a form of doing" (58) and proposes that kinship, though mostly read as pre-political, in fact provides "the mediating link...between the public and private spheres" (81). This suggestion to understand kinship as performative can be read in line with Butler's earlier and continued work on performative acts, in which she develops from J. L. Austin's speech act theory a model of identity performativity. Following her rationale above, that the terms of kinship have been radically altered and are by no means defined by blood relation only, one may well draw a line between Esposito's suggestion to understand communitas as a relationship based on recognizing the mutual obligation to give something to the community and Aghaza's choice to grieve and bury her husband's erstwhile guest. Her action follows in direct and logical consequence to Joqola's earlier choice, at the beginning of the play, to recognize Zviadauri as his guest - a choice by which he enters the three of them into a relationship of mutual gratitude and obligation, a community parallel to their ancestral communities.

In Antigone's Claim (2000), Butler already discusses "which social arrangements can be recognized as legitimate love, and which human losses can be explicitly grieved as real and consequential loss" (24). But it is in her later essays on war and grief (Precarious Life, 2004, and Frames of War, 2009) that she comprehensively explores how the objectification and dehumanization of the cultural Other allows for the withholding of grief and for the killing of the Other. She argues that while we protect certain lives, while the termination of their claims to sanctity are sufficient to mobilize the forces of war, other lives are not subject to this protection and do not qualify as "grievable," either (Precarious Life 32). The value of life is only ever asserted in the possibility of its loss, in its precariousness, she reasons, when it is determined whether the loss of a certain life would matter or not: "grievability is a presupposition for the life that matters" (Frames of War 14).

The division into grievable and ungrievable lives, into lives "perceived as lives" and those which, "though apparently living, fail to assume perceptual form as such," allows for the sorting of populations into groups of those whose lives need to be preserved and those whose loss is acceptable (24). The fact that a life is always threatened by its eventual loss leads "to a specific exploitation of targeted populations, of lives that are not quite lives": lives that have been framed as dispensable and thus have become dispensable. In spite of their obvious precariousness, they are not perceived as vulnerable and in need of protection but rather as a threat to those lives which are recognised as grievable, as actual lives (31). The division of the world population into lives that are grievable and ungrievable can be observed "from the perspective of those who wage war in order to defend the lives of certain communities, and to defend them against the 
lives of others - even if it means taking those latter lives” (38). The ungrievable lives cannot be mourned, Butler emphasises,

because they are always already lost, or, rather, never 'were,' and they must be killed, since they seem to live on, stubbornly, in this state of deadness. Violence renews itself in the face of the apparent inexhaustibility of its object. The derealization of the 'Other' means that it is neither alive nor dead, but interminably spectral. The infinite paranoia that imagines the war against terrorism as a war without end will be one that justifies itself endlessly in relation to the spectral infinity of its enemy, regardless of whether or not there are established grounds to suspect the continuing operation of terror cells with violent aims. (Precarious Life 33-4)

In Host and Guest, there is a thought-provoking confrontation between the community of the still-living and that of the 'interminably spectral'. Not only visually, the scene in which Aghaza is haunted by the dead is an echo of S. Ansky's 1920 play The Dybbuk, or Between Two Worlds, which famously features a young brideto-be dancing with the dead souls in the graveyard. The haunting in The Dybbuk of course has a different reason, but the background is related - the Shtetl in Ansky's play is haunted by an equally long and traumatising history of violence and loss as is the Kisti village in Host and Guest. By leaving Zviadauri unburied, the Kisti have broken another taboo, as the line between life and death is being blurred, pointing at the evil both introjected and projected in Derrida's sense.

Butler speaks out against the idea that grief is privatising and depoliticizing. She argues instead that it offers a sense of political community of a complex order by emphasising the relational ties and their implications for theorising mutual dependency and ethical responsibility (Precarious Life 22). Grief should be a "point of departure for a new understanding," she states, "if the narcissistic preoccupation of melancholia can be moved into a consideration of the vulnerability of others" (30). Inclined to thinking theory through theatre, she returns to another ancient Greek play, to Aeschylus's Oresteia, to propose refusing the cycle of violence in the name of justice founded in grief, to form the world anew by taking into account how it came to be involved in this cycle of mourning and violence in the first place (17).

When, in Host and Guest, the neighbouring Khevsuri attack to avenge Zviadauri's death and recapture his body, his erstwhile host Joqola dies in the battle because he has been cast out, the other Kisti warriors refuse to help him - and Aghaza, who is also shunned by the community, eventually takes her own life:

The defeated Kistis drag Aghaza out of the house and throw her to the ground. She rises to her knees, but refuses to weep. The men stand around her.

Mullah You wept for the foreign enemy, now go weep for your traitor husband. $\mathbf{1}^{\text {st }}$ Parishioner Your guest's people have slaughtered Joqola, butchered him. $2^{\text {nd }}$ Parishioner Do you still weep for our enemy? 


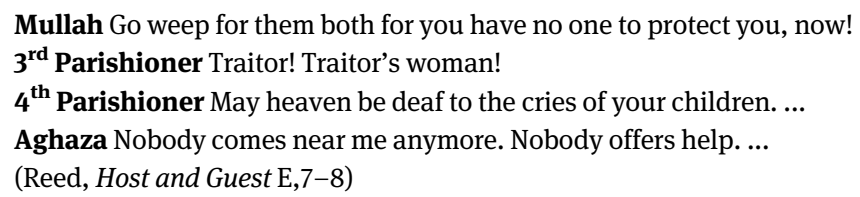

The villagers' outrage at Aghaza's transgressive act invites a perspective on the larger implications of the play and its performance just outside the capital city of one of the most powerful states of the global North and in the language that has long become the language of globalization. In her work on the connection between simultaneous border consolidation and a decline in national sovereignty in a globalised world, Wendy Brown traces the trend to "increasingly liberalized borders, on the one hand," and to "border fortification, on the other" (8). When she discusses the possible reasons for the general desire of the "global North" she calls it "the Euro-Atlantic world" (125) to erect walls around itself, and the connected desire to generate a "hysteria about permeability, immigrants, or even terror," she suggests these desires might be read as a Freudian phobia or obsession: as a substitute or surrogate for ideas incompatible with the ego's notion of itself. The unacceptable ideas, Brown points out, may pertain to one or more of the following features of contemporary existence:

the limited capacity for (economic, cultural, and even legal) containment exercised by the nation-state today; the weakening of sovereign protective capacities; the declining power and supremacy of the Euro-Atlantic world and the attendant loss of status for the working and middle classes; the erosion of national identity based on a shared language and culture; the reliance of the Euro-Atlantic prosperity on the production of an impoverished outside; perhaps above all, a Euro-Atlantic existence full of crime, drugs, violence, ennui, depression and drained of its secure economic might, social stability, political power, and cultural supremacy. The hysterical obsession is The Alien, fashioned as a single imaginary creature from the material of immigrants, drug traffickers, and terrorists and representing the pollution of violated borders and the demasculinization of a permeable national and individual subjecthood. (Brown 125)

In its depiction of a community that defines itself ferociously by a sharp delineation between inside and outside, casting the outside as the enemy, Host and Guest speaks strongly to the contemporary urge to exclude rather than to include. Evidently, this urge is not a contemporary urge at all, but it is being counterargued by an increasing globalization, by the other side of the exclusion, the privileged, elective mobility of an interconnected elite.

As can be concluded from the ever-increasing number of plays and performances featuring refugees, illegal immigrants, and other instances of people existing at the fringes of society or fully outside any legal or political framework, and following further examples of eroding nation states, the increase in the global 
North's 'walls up' policies with regard to immigration, and a general recognition of biopolitics as a dominant feature of modernity, the bare life (or the precarious life, or a figure like it) is a figure which has emerged more and more on the theatrical stage, demanding the exploration of ethical questions in view of such developments. This raises the question whether the theatre might be the public space where it is currently possible to think about the relationship between the displaced, the unwanted, and the community as both an ethical and a political question. In her writing on performance and utopia, Jill Dolan understands the theatre as "the possibility of a better future, one that can be captured and claimed in performance," stating that

[u]topian performatives describe small but profound moments in which performance calls the attention of the audience in a way that lifts everyone slightly above the present, into a hopeful feeling of what the world might be like if every moment of our lives were as emotionally voluminous, generous, aesthetically striking, and intersubjectively intense. (Dolan 5-7)

Reading utopian performatives as a 'doing' in J. L. Austin's sense of the term, something that performs an action, Dolan argues that the theatre "offers a place to embody and, even if through fantasy, enact the affective possibilities of 'doings' that gesture toward a much better world" (8). She suggests that these "affective and ideological 'doings"' that can be witnessed in utopian performatives should be seen as critical rehearsals for "civic engagement that could be effective in the wider public and political realm” (8). Connecting Dolan's theory to both Butler's earlier suggestion to read kinship as a form of doing and to Esposito's proposal to understand communitas as a continuous mutual obligation to fill the lack at the centre of the community, it is possible to understand community as a form of kinship by choice, as a relationship that is actively forged by choosing to take up the obligation and acting upon it.

If we elect to understand the theatrical arts as the subjunctive, where utopia is 'always in process', and if we decide to regard the utopian as a process involving human agency, then the experience of attending a theatrical performance such as Synetic Theater's production allows for an active choice to be response-able, for the intersubjective creation of communitas in Esposito's sense as a 'gift to the other.' If we choose to read the utopian in this way, the theatre could become an incentive to create a better future.

Precisely because of its relative simplicity, the play can be read in the tradition of Bertold Brecht's parable plays and be used to explore theoretical concepts in the way of a thought experiment. While several critics have read Host and Guest as a folkloristic story of violence conducted 'in the name of tribalism' (e.g. Treanor, See, and Arion), I would argue that the main theme of the play is the notion of 
hospitality and compassion, though these are clearly not portrayed as the founding principles of communities. Esposito is one among several critics to point out that communities are forged by an initial and often violent sacrifice, by an act of forceful exclusion (33-4). Brown also points out that the fencing off of a space comes right at the beginning of civilization (43). But the play argues for compassion and hospitality as the underlying directive to strive for in a community. There are two versions of community in Host and Guest: one is the Kisti community, which insists Joqola should hand over Zviadauri so that he can be sacrificed and the community's thirst for revenge can be stilled - it is a community which defines itself by the notion of the individual owing something to the community. And then, there is the other, the parallel, community in this play, forged briefly only in the characters' lives: the host-guest relationship between Joqola, Zviadauri and Aghaza, closer to Esposito's etymologically unpacked concept of communitas: the gift to the other by obligation - I owe you hospitality - is understood as the main rule of the community. In line with the above notion of utopian thought and how it bears upon contemporary performance, Esposito insists that "[i]f the community belongs to us as our deepest and most proper root, we can, in fact we must, find it again or reproduce it, in line with its originary essence" (16). The play ends on the three characters finding each other in death, as spirits, reenacting the host situation: three humans sharing a meal around a fire.

\section{Works Cited}

\section{Primary Literature}

Ansky, S. The Dybbuk. A Play in Four Acts. 1926. Trans. Henry G. Alsberg and Winifred Katzin. New York: Liveright, 1971. Print.

Host and Guest. By Roland Reed. Dir. Paata Tsikurishvili. Choreo. Irina Tsikirishvili. Comp. Vato Kakhidze. Perf. Irina Tsikurishvili, Greg Marzullo, Irakli Kavsadze, et al. Produced by Synetic Theatre. Rosslyn Spectrum, Arlington, VA. 31 Oct. - 22 Dec. 2002. Videotaped by James J. Taylor for Blueline Studio. Recorded 20 December 2002. WAP 0006, tape number 311. The Washington Area Performing Arts Video Archive (WAPAVA), University of Maryland, College Park, MD. Accessed 26 November 2013. Performance Recording: 1 videodisc (77 min.).

Host \& Guest Trailer. Synetic Theater. Filmed and edited by silhouettefilm, Oct. 2008. Youtube video. <youtu.be/ZEuJCVC4jt0> (Date of access: 25 May 2016).

Reed, Roland L. The Host and the Guest. Based on Vazha-Pshavela's Narrative Poem, "Host and Guest” (1893). Washington, DC: Synetic Theater, 2002. Emailed to the author by Synetic Theater's Development and Events Manager Monica Jilling on 13 January 2014. Typescript. 


\section{Secondary Literature}

Agamben, Giorgio. Homo Sacer. Sovereign Power and Bare Life. 1995. Trans. Daniel HellerRoazen. Stanford: Stanford University Press, 1998. Print.

Austin, John Langshaw. How to Do Things with Words. Cambridge: Harvard University Press, 1975. Print.

Berger, Arion. "Revenge Is Bitter: Synetic Theater's 'Host and Guest'." The Washington Post, $10 c t$. 2008. Web. <washingtonpost.com/express/wp/2008/10/02/revenge_is_bitter_ synetic_theaters_host/>. (Date of access: 24 May 2016).

Blanchard, Jayne. "Unforgettable 'Host'." The Washington Times. 1 Oct. 2008. Web. <washingtontimes.com/news/2008/oct/01/unforgettable-host/?page=all>. (Date of access: 24 May 2016).

Brown, Wendy. Walled States, Waning Sovereignity. 2010. Cambridge: MIT Press, 2014. Kindle file.

Butler, Judith. Antigone's Claim. Kinship Between Life and Death. New York: Columbia UP, 2000. Print.

Butler, Judith. Precarious Life. The Powers of Mourning and Violence. New York: Verso, 2004. Print.

Butler, Judith. Frames of War. When Is Life Grievable? London and New York: Verso, 2009. Print. Campbell, Timothy. “Interview with Roberto Esposito.” Diacritics 36.2 (2006): 49-56. Print. Derrida, Jacques. “Plato’s Pharmacy.” 1968 (in Tel Quel). Dissemination. 1972. Trans. Barbara Johnson. Chicago: University of Chicago Press, 1981, 61-171. Print.

Derrida, Jacques. The Beast and the Sovereign, Volume 1. 2008. Trans. Geoffrey Bennington. Chicago: University of Chicago Press, 2009. Kindle file.

Dolan, Jill. Utopia in Performance. Finding Hope at the Theater. Ann Arbor: University of Michigan Press, 2005. Print.

Esposito, Roberto. Communitas. The Origin and Destiny of Community. 1998. Trans. Timothy Campbell. Stanford: Stanford UP, 2010. Print.

Girard, René. The Scapegoat. 1982. Trans. Yvonne Freccero. London and New York: Continuum, 2005. Print.

Girard, René. Violence and the Sacred. 1972. Trans. Patrick Gregory. London and New York: Continuum, 2005. Print.

Marks, Peter. “'Host and Guest': Back with a Vengeance.” The Washington Post, 29 September 2008. Web. <washingtonpost.com/wp-dyn/content/article/2008/09/28/ AR2008092802552.html>. (Date of access: 24 May 2016).

Rancière, Jacques. “Who is the Subject of the Rights of Man?” The South Atlantic Quarterly 103.2/ 3 (Spring/Summer 2004): 297-310. Print.

See, Rich. "Host and Guest." curtainup.com, 3 September 2004. Web. <dctheatrescene.com/ 2008/09/30/host-and-guest/>. (Date of access: 24 May 2016).

Treanor, Tim. "Host and Guest." dctheatrescene.com, 30 Sept. 2008. Web. <curtainup.com/ hostandguest.html> (Date of access: 24 May 2016). 


\section{Bionote}

\section{Julia Boll}

Julia Boll holds a doctorate in drama from the University of Edinburgh. She was a director of the Scottish Universities' International Summer School, a teaching assistant at the University of Edinburgh, and also worked for the Edinburgh Review. In 2013, she joined the University of Konstanz as a Marie Sktodowska Curie Fellow to research the representation of the bare life on stage; a project for which, as PI, she received funding from the German Research Foundation (DFG) in 2015. Since 2012, she has also been a member of the multi-disciplinary research project Fiction Meets Science (Univs. of Bremen and Oldenburg). Her monograph The New War Plays: From Kane to Harris was published by Palgrave Macmillan in October 2013. 